\title{
New Histories: Creating Video Work to Fill Adoption Absences
}

\section{CHRISTINE ROGERS}

\begin{abstract}
Adopted at birth and brought up Pākehā, I discovered as an adult that I have Ngāi Tahu tūpuna (ancestors). Adoptees seek birth kin and stories to try to fill the gaps and absences that haunt us, so I undertook my roots journey, travelling three times to Riverton/Aparima, where my ancestors had lived, taking my video camera. In this article I describe how initially I did not find the belonging I was looking for, but through my creative practice of filmmaking, and the three short videos I made, I did connect to place, and began making a new history for myself.
\end{abstract}

\section{Introduction}

I was born in Christchurch, one of over 3,000 illegitimate children born in 1965 in Aotearoa/New Zealand, and almost immediately given away in a closed stranger adoption. ${ }^{1}$ My birth parents were strangers to my adoptive parents, and I was issued with a birth certificate that listed my adoptive parents as my parents. ${ }^{2}$ With this severing, I was split from my own past, and absences and silences haunted me as I grew up. In 1985, the Aotearoa/New Zealand Parliament passed the Adult Adoption Information Act, ${ }^{3}$ and I began the search for information on my birth parents. At first, I was unsuccessful. Then, around the age of 30, with the assistance of a social worker, I met my birth father, Brian. This was when I found that some of my ancestors were Ngāi Tahu. ${ }^{4}$ I was subsequently enrolled officially as Ngāi Tahu and given my whakapapa (genealogy). ${ }^{5}$ This part of my ancestry lived in the background of my life until recently, when I began a creative practice $\mathrm{PhD}$, and through research and creative practice, looked for a way to make this erased history my story.

In this article, I discuss how in order to make this abstract history real to me I travelled from my home in Australia to Riverton/Aparima, the place where my ancestors lived and died, taking my video camera. Using the methodologies of creative practice research and autoethnography, framed by the concept of hauntology, I went looking for ghosts - seeking my ancestors in what I imagined to be an uneasy colonial landscape. However, at first, I did not find what I hoped for. I travelled three times to Riverton/Aparima, making three short videos (which can be viewed via links), and through this I brought the past into conversation with the present, and made memories of place that help ease adoption loss.

\section{Adoption: Absence and Gaps}

The absences at the heart of adoption have shaped my life. Betty Jean Lifton, told at the age of seven that she was adopted, repressed her painful feelings, and writes that through this she became someone "unreal pretending to be real." 6 In a national research study in Australia which surveyed over 800 adoptees, 70 percent of respondents agreed that being adopted had resulted in negative effects on their mental, physical and emotional health. ${ }^{7}$ The term "genealogical bewilderment" was first used in the 1950s as a mental health diagnosis, but it was taken up by many in the adoption community in the 1970s to describe the distress and pain of not knowing who our birth parents are. ${ }^{8}$ One way to combat this bewilderment is through imagination and invention.

I have always told myself stories to fill the void. Anne Harris, a fellow adoptee, concludes that we are "narrative whores. For us, any story will do. Story is no different than history, lies, 
fiction, and fact, because absence makes it all the same." 9 Story making is now seen as vital for modern adoptees, who are encouraged to construct a "life story" document to build a coherent story about their past. Interestingly, fictions are just as successful for helping adoptees build a viable past, and through this, realise a present. ${ }^{10}$ Meghann Ormond's adopted mother responded to the silences in her past by obsessively collecting stories, documents and photographs from her birth kin and making a creative bricolage, building her own fragmentary origin stories. ${ }^{11}$ My video practice is part of how I am building my own origin stories, and the stories I am focusing on are those of my Ngāi Tahu tūpuna.

I am powerfully drawn to these ancestors for several interrelated reasons. These are my birth father's people, and I had a loving relationship with him, unlike the relationship with my birth mother, which broke down after several years. There are also complex ideas here around finding an "authentic" identity, as adoptees often feel unseen to others and ourselves. ${ }^{12} \mathrm{My}$ Ngāi Tahu tūpuna tap into the beguiling idea that to have indigenous ancestry is to be "born from the earth itself" rather than transplanted. ${ }^{13}$ Certainly, many of us in settler nations whose ancestors transplanted themselves live with complex and contested belongings, ${ }^{14}$ as is the case with Pākehā, as Avril Bell has convincingly argued. ${ }^{15}$

\section{Autoethnography: Embodied and Intuitive Knowledges}

In this work I am "thinking with video" in creative practice research, and through this, engaging with different kinds of knowledges. ${ }^{16}$ Alongside this, I am using autoethnography as method and methodology, weaving story and theory together, looking inward to my own experiences, and outward to culture and society. ${ }^{17}$ Autoethnography is an embodied practice; researchers go out into the field, experiencing self and culture in practice. ${ }^{18}$ It is a practice that encourages us to tell outsider stories, ${ }^{19}$ and through this, ally ourselves with marginalised groups. ${ }^{20}$ This reflective methodology can help break down "mind-supremacist" thinking that devalues other more uncertain and subtle knowledges. ${ }^{21}$ Personal narratives can more fully convey the obscure, the peculiar, and the darkness of human experience. ${ }^{22}$ Stacey Holman Jones contends this work should be uncomfortable for writer and reader, and she urges us to "create disturbances" and make the personal political to encourage change. ${ }^{23}$ Reena Veralynne Kainamu writes, in her Māori indigene autoethnography, that she wants her research to sit in a space where there is "difference or conflict or awe or tension," where it might get under the skin of the reader, allowing a deeper connection to be made. ${ }^{24}$ Certainly, travelling to the land of my ancestors and stepping into a Māori cultural space unsettles already unsettled narratives around identity and belonging. Autoethnography encourages me to go there, and to write of the frustrations and messiness.

This brings me to an important question: is it my right to tell the stories of my Māori ancestors? I am essentially a "Pākehā with a whakapapa," a term Tā (Sir) Tipene O'Regan was called in an argument with Te Arawa, to which he replied "I certainly wasn't going to claim that I was a Māori. I wasn't! I was Ngāi Tahu, and that was something that he couldn't deny." 25 This speaks powerfully to the contested in-between nature of Ngāi Tahu identity, distinguished by early and extensive intermarriage with settlers. ${ }^{26}$

Linda Tuhiwai Smith reminds me that questions about indigenous "authenticity" are loaded:

These debates are designed to fragment and marginalise those who speak for, or in support of, indigenous issues. They frequently have the effect also of silencing and making invisible the presence of other groups within the indigenous society like women . . . and those whose ancestry or "blood quantum" is "too white.",27 
This fits with the autoethnographic call to allow voices to speak that might otherwise remain silent and to tell oppositional rather than normative stories. ${ }^{28}$ However, let me be clear what I'm not doing. I am not what Paul Whitinui calls a "Native" researcher-I do connect genetically to someone who is Native, but I cannot "intimately speak about the cultural underlays/overlays associated with time, space, place and identity." ${ }^{29}$ I acknowledge the privilege that my white racial identity has given me, but I cannot shuck this off like a coat. The space I claim is that of an adoptee exploring her tūpuna, trying at all times to work in an ethical way, wary of appropriating, re-colonising and reducing complexities to superficialities ${ }^{30} \mathrm{My}$ space as an adoptee is personal and political-my in-betweenness and ultimately unsolvable attempts to fit, to be "either this or that" reveal the vulnerabilities of all identities. ${ }^{31}$

\section{Hauntology: Ghosts on the Landscape}

Mieke Bal argues that a concept-based methodology is vital because concepts, or "miniature theories," help "articulate an understanding, convey an interpretation... or enable a discussion" as they travel and morph between disciplines, scholars, and periods of time. ${ }^{32}$ The concept that I am using is hauntology. This is not Jacques Derrida's hauntology, according to which he argues that the spectre of Marxism was haunting modernity, ${ }^{33}$ but hauntology as postcolonial scholars use it, allowing us to talk about the landscape as a place where the border between the past and present is fluid, an unfinished, contested place that contains "histories that cannot rest." 34 For Eve Tuck and C. Ree, hauntology describes the "relentless remembering and reminding" of a brutal colonial past that will not be appeased and won't ever go away. ${ }^{35}$ Avery Gordon uses it to talk about "lingering trouble"; violence concealed but present, and she urges us to follow ghosts as a way of "putting life back in where only a vague memory or a bare trace was visible to those who bothered to look." ${ }^{36}$ Esther Fitzpatrick bothered to look, using hauntology to speak about the ghosts of her colonial Pākehā ancestors, hoping in this way to achieve some small justice. ${ }^{37}$ As an adoptee, growing up haunted by the ghosts of my birth family and the self I might have been, this concept is potent, and with it I hoped to find a way to "speak to the specter" 38 when I visited the landscape of my ancestors.

\section{Ngāi Tahu, A Southern People}

The constraints on word length in this article prevent a lengthy Ngāi Tahu history, but some personal history will provide context. One of my great-great-great-grandmothers, Meri Wehikore, "descended from chiefs," 39 was married by Bishop Selwyn to James Leader, an English sealer and whaler, in $1844 .{ }^{40}$ James drowned in Jacob's River in 1852, and their three young children James, Eliza, and Elizabeth were then brought up by Captain John Howell and his second wife Caroline/Koronaki. ${ }^{41}$ In all likelihood they were brought up Pākehā. Howell, a leading Riverton/Aparima entrepreneur and Leader's sometime employer, forbade Caroline, who was mixed-race, from attending Māori church services or associating with her Māori relatives. ${ }^{42}$ Elizabeth, my great-great-grandmother, married John Arnett, whose mother, Haerenoa Te Anu, was also Ngāi Tahu. Both Meri and Haerenoa were from the Aparima hapū (sub-tribe) in the far south, and they were part of a story that involved the highest rates of interracial relationships in Aotearoa/New Zealand.

\section{Early Contact, Early Connection}

Europeans began arriving in Southland from 1780, for the most part sealers and whalers lured by accounts of the treasures in the surrounding seas, where over one million seals were slaughtered between 1804 and $1809 .{ }^{43}$ But the real flood of foreigners came for whales-by the mid 1840s there were at least 800 men working around Cook Strait alone. Shore-based

Journal of New Zealand Studies NS29 (2019), 75-88 https://doi.org/10.26686/jnzs.v0iNS29.6263 
whaling predominated, and settlements needed food and labour. ${ }^{44}$ In this early period both Pākehā and Māori modified behaviours and culture, willing to learn and compromise, ${ }^{45}$ and relationships between Ngāi Tahu women and Pākehā men flourished. In 1844, New Zealand Company surveyor Frederick Tuckett estimated that from Banks Peninsular to Riverton/Aparima, "two-thirds of the native women, who are not aged, are living with Europeans." ${ }^{\prime 6}$ In 1864, when the final Crown purchase of Ngāi Tahu land was completed, an incredible 68 percent of the Foveaux Strait population was of mixed-race. ${ }^{47}$ In comparison, in census dating from 1861 to 1921, mixed-descent individuals across the North Island never consisted of more than around 14 percent of the population. ${ }^{48}$

For women such as my tūpuna, a relationship with a Pākehā may have brought mana (prestige) to her and her iwi because of access to resources. John Boultbee wrote that "the father of a family will sell a daughter or two or three, if required, for a musket each!" 49 However, firsthand accounts of this time are almost exclusively limited to the white male voice, ${ }^{50}$ so it's likely relationships were often more nuanced than this. Women had a great deal of say in the relationships they entered into, ${ }^{51}$ and marriage was used to draw Pākehā into whakapapa, cement alliances, and avoid conflict. ${ }^{52}$ By 1840, a particular marriage culture had evolved which combined Māori customs of public acknowledgement and gift giving with common maritime practices. ${ }^{53}$ Some couples married again when a representative of the Christian church showed up, as James and Meri did. These early relationships have left a lasting legacy-seen as "Pākehāfied," 54 Ngāi Tahu are still sometimes called the "white tribe." ${ }^{55}$ It is to this difficult in-betweenness that both myself and my ancestors belong.

Elizabeth, her husband John, and their many siblings were "hawhe kaihe" — "half-caste," and mixed-race children were viewed by many of their peers with suspicion. ${ }^{56}$ Contemporary Māori terms included "utu pihikete" (paid for in biscuits), "huipaiana" (an iron hoop, also an item of trade), and "o te parara" (out of the [whalers'] barrel). ${ }^{57}$ Mixed-race people were, and Stan Grant argues, continue to be, destabilizing. ${ }^{58}$ A glimpse of the complexities of miscegenation can be seen in a letter in a local paper correcting John on a matter regarding the Riverton/Aparima Native School; "The school was erected for the Natives, not for the halfcastes." 59

\section{The Archives; The Past in Dialogue with the Present}

To begin to know my tūpuna I turned first to archives, and these were across the spectrum, from the official archives of Ngāi Tahu and government documents, where collection occurs in a closed system with complex criteria of value, ${ }^{60}$ to the chaos of materials gathered by amateur historians and genealogists which more closely illustrate Tim Cresswell's "contingent, messy and permeable" archives. ${ }^{61}$ I had been given my official genealogy charts when I first registered - two beautiful, handwritten, A3 sheets which showed me some of the lines of the Arnett, Green and Leader families. Subsequently, I spent time at Ngāi Tahu headquarters, browsing several large folders filled with documents pertaining to these three lines of descent. Some of these were from official sources but many were informal; genealogies, unlabelled photographs, handwritten notes. Later, I would encounter informal archives again in the gentle chaos in the back room of the Riverton/Aparima museum.

The archival research phrase of my research was fruitful, but the partial stories that I gleaned remained frustratingly abstract. I realised that I needed to travel to Riverton/Aparima where my ancestors had lived, to experience this abstract knowledge in a more subjective, embodied way. I wanted to see if the past was present in the landscape, as hauntology had suggested it 
would be, and to build memories; after all, disappointing journeys are perhaps the most memorable of all. I hoped to turn a landscape, seen online in images and maps, a place I was outside of, into place, because as Cresswell argues, "places are very much things to be inside of." 62 I went there because I wanted to be inside this story.

In undertaking this journey, I was using the ethnographic practice of participant-observation fieldwork; site-specific research where the body is privileged as a site of knowing. ${ }^{63} \mathrm{I}$ was also following Tim Ingold's argument that there is no separation between being and knowing, and that we can only know by doing - "knowing is a process of active following, of going along." 64 I was "going along" to the far south of Aotearoa/New Zealand, to see, and to film, and through this I hoped to know more about my ancestors and about myself.

I made three visits to Riverton/Aparima, and each time I took a video camera to give me agency and direct my travel. Taking a camera meant I would be present twice. Once, in the time of the shoot, and then again in the more sustained time of the edit. Pre-visit I was nervous, filled with an adoptee's fear of not belonging. I emailed local iwi but had been unsuccessful in setting up a meeting. But I did not persist-I did not want to be rejected as the "pushy" Pākehā. Being adopted had meant losing the right to find out about my past, so this is a space where I am now very tentative. ${ }^{65}$

\section{Place, and Māori Knowledges of Place}

On my way south I visited the Ngāi Tahu research collection at Canterbury University, and was thrilled to be given my ancestral pepeha (formal introduction) by Nekerangi Paul, Kaitakawaenga Māori. ${ }^{66} \mathrm{I}$ immediately saw from this how central place is in a Māori world view. A pepeha is a way for people to "bespeak our landscapes in which are embodied our founding ancestors, ${ }^{, 67}$ and the Arnetts speak themselves in relation to Aoraki, to Te Ara a Kewa (Foveaux Strait), and to our far ancestors Rakaihautu and Paikea, who made the features of the land. For Māori, land was life itself - "there was no part of early Māori culture that was not touched by the land." ${ }^{68}$ Whenua, the land where you are born, which also means afterbirth, ${ }^{69}$ and where you live is who you are, expressed in the idea of Turangawaewae, a "place to stand," where one has the right to belong through ties to ancestors. ${ }^{70}$ It was this power of blood that I was hoping to be connected into.

\section{Easter 2017: Visit One}

When researchers go out in the field, sometimes the theories we bring with us, vivid and appealing on the page, fail to speak, and cannot help us make sense of what we find. ${ }^{71}$ This was the case with the concept of hauntology for me. Rather than finding a troubled landscape reflecting the strangeness and complexity of my roots journey, I found Riverton/Aparima to be a lovely, placid, typical Aotearoa/New Zealand small town. There were suburban houses with flowering gardens, a rugby field, a slow winding river, a stony beach. Surrounding the town were green paddocks, bordered by mountains. The only immediate signs of Ngāi Tahu were in the museum and on the marae, the latter of which I could not visit, knowing no one. ${ }^{72}$

Still, I had travelled with an agenda; I had five old maps given to me by Helen Brown in the Ngāi Tahu Christchurch office, maps of properties that my great-great-grandfather John Arnett bequeathed to his eight children when he died in 1895. These were pieces of land where people of my blood had lived, and perhaps died, and my plan was to find them and film them. This turned out to be an inexact science-some properties we had been able to transpose to modern maps, but others were more difficult. Two large sections on a map titled Jacob's River Hundred 
Native Reserve were now part of the municipal rubbish dump. Another was the rugby field. Another, pasture in Colac Bay, the road closed in front of it and crumbling into the sea. The last, labelled "HALF CAST CLAIM" on the old map, was also pasture, in Longwood, a rural district inland, indivisible from the paddocks either side.

We drove (I was with my husband), I filmed, and all day I felt self-conscious, ridiculous, like an imposter. What had I been imagining, that the past would be waiting there for me, congealed in aspic, a living museum display? Barbara Yngvesson reminds me that for adoptees, the birth country can be "a powerful site where the potential and the impossibility of full belonging may be experienced." 73 The only place I felt belonging was deep in a stand of old macrocarpa trees on the edge of the rugby ground, where I was tugged into memory-of my childhood in Christchurch, where I had spent many happy hours playing alone on the abandoned property next door, beneath the same ancient trees.

I took this footage home and for a long time I worked with it, trying to tell a story that gave a sense of the complexity that this land held for me. Certainly, there was nothing in my images that spoke of the "unfinished, contested nature of colonial and postcolonial geographies" that hauntology suggests. ${ }^{74}$ I knew that I needed to put myself into the work but also keep a fluidity of meaning - for the work to be an enquiry, not a statement. ${ }^{75}$ It was my husband who suggested I record a song as the soundtrack, and the possibility of the poetics of a song immediately appealed. I found "Davy Lowston," a Victorian era ballad about sealers abandoned in Southland, in 1810, and I wrote new lyrics telling the story of John Arnett. I am an amateur singer, and the final song certainly has autoethnographic vulnerability! The final short film John Arnett-Five Properties introduces John as "neither Pākehā, neither Māori," and I argue it evokes some of my feelings about my in-between ancestor.

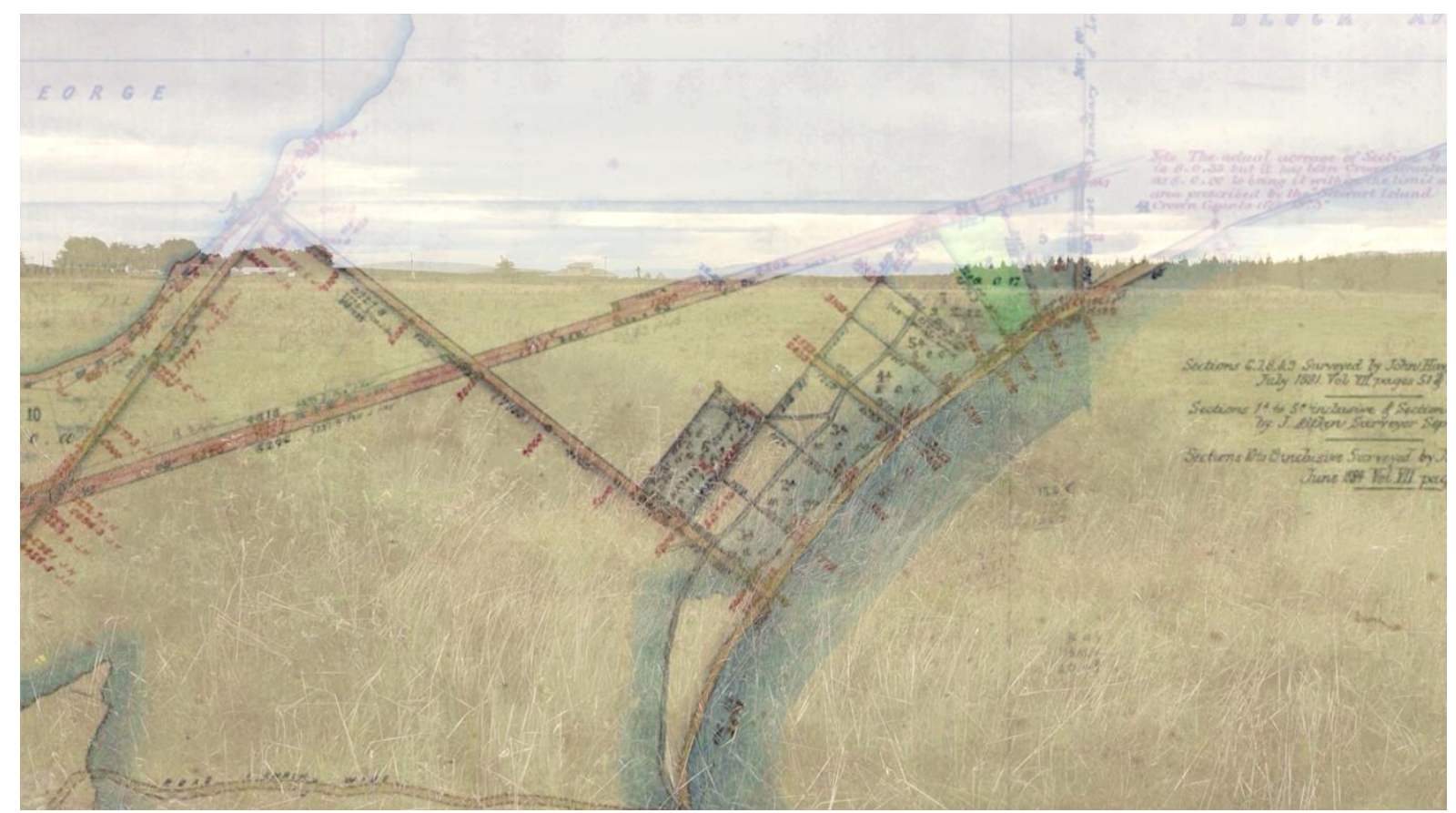

Figure 1. Frame from John Arnett—Five Properties. Map courtesy of Helen Brown, Te Rūnanga o Ngāi Tahu.

After the edit I became keen to return, but this time incorporating some of the costume work I

Journal of New Zealand Studies NS29 (2019), 75-88 https://doi.org/10.26686/jnzs.v0iNS29.6263 
had been experimenting with. I had been filming myself in Victorian costume as a creative response to a nineteenth century hand-coloured photograph I have of Elizabeth Arnett. In the photo she wears an elaborate Victorian dress, no part of her Ngāi Tahu identity on display. Kate Stevens reminds me that it was seen as increasingly desirable, from the mid nineteenth century, for mixed-race women to "pass" in settler society for Pākehā. ${ }^{76}$ I decided to film myself wearing the kind of Victorian boots that Elizabeth might have worn. I acknowledge that I cannot pretend to know how Elizabeth felt about what she wore, but I was hoping to use the boots as a way of stepping out of my everyday identity, in the way that clothing can help us shift our self from one mode of being to another. ${ }^{77}$ I was trying what Vanessa Agnew describes as "substitution - the reenactor for the historical agent [and] the present for the past," and through this to perhaps experience some of the haunting that had eluded me. ${ }^{78} \mathrm{I}$ also hired a local drone photographer to gain a different view of the same properties; to try to see further, to see more.

\section{Winter 2018: Visit Two}

This time I travelled alone, taking my camera and the pair of ersatz Victorian boots, and a plan to film myself walking in the boots. Walking with camera is a method used by such diverse videographers such as Marsha Berry, Sarah Pink, and Dean Keep. Berry contends that with this method she works with "geographic ways of knowing," and that it helps her express the dynamic, multifaceted nature of landscapes and our relationships with them. ${ }^{79}$ Pink argues that walking with a camera requires a particular reflexivity; for her the practice is place making. ${ }^{80}$

This time I felt the familiarity of visiting a place I had been before, but I also felt shock at some of the changes that had been wrought. The large section of mature macrocarpa trees, where I had connected with my childhood, had been cut down. I was on Elspeth Probyn's "threshold"no longer a stranger, but not belonging either. ${ }^{81}$ I also met several local Ngāi Tahu, including Mrs. Leader, a distant relative, and I was thrilled to see a taiaha (long war club) on her wall that she explained had been handed down to her from her (our) ancestors.

After the drone shoot, I filmed myself walking in the Victorian boots; on the rugby field, through tussocks and out to the beach and through a nature reserve between Riverton/Aparima and Colac Bay. I was not able to walk on the other four properties as they are fenced off and private property. The boots certainly changed my motility-I felt constrained and precarious, especially on the stony shoreline. But at the same time, I moved with more confidence, no longer frightened of being asked to leave.

Sitting down to the edit, I again struggled with how to show what this place meant to me-to show the picaresque but to talk of the complexity and darkness, and to "make the absent present." ${ }^{\circ 2}$ The drone footage was beautiful, the bird's-eye view a welcome reprieve from our earthbound vision. The footage of walking was lurching, difficult to watch, so I slowed this down, adding gravitas and a feeling of melancholy. I was most captivated by the images from the reserve. The bush had been a diversion, although it is likely my whānau would have walked there. It was here that I had felt a powerful belonging, where the edges between myself and the world vanished, a moment which Ann Game describes as "full and alive in its connectedness" - a connection, again, to my childhood and holidays on the West Coast. ${ }^{83}$

Eventually, I decided to tell a story in voice-over that directly engages with the notion of hauntology. The resulting short film, Looking Forward, Walking Down, is an essay film, an autoethnographic genre which is typically fluid, questioning and open-ended. ${ }^{84}$ Looking 
Forward, Walking Down is a meditation on place and belonging. I employ cinematic techniques of slow motion, superimposition and split screens to visually represent the gaps and shifts between the past and the present. ${ }^{85}$ Through this, and the personal voice-over, I hope to give some sense of my relationship to Riverton/Aparima, and what I found when I went ghosthunting. ${ }^{86}$

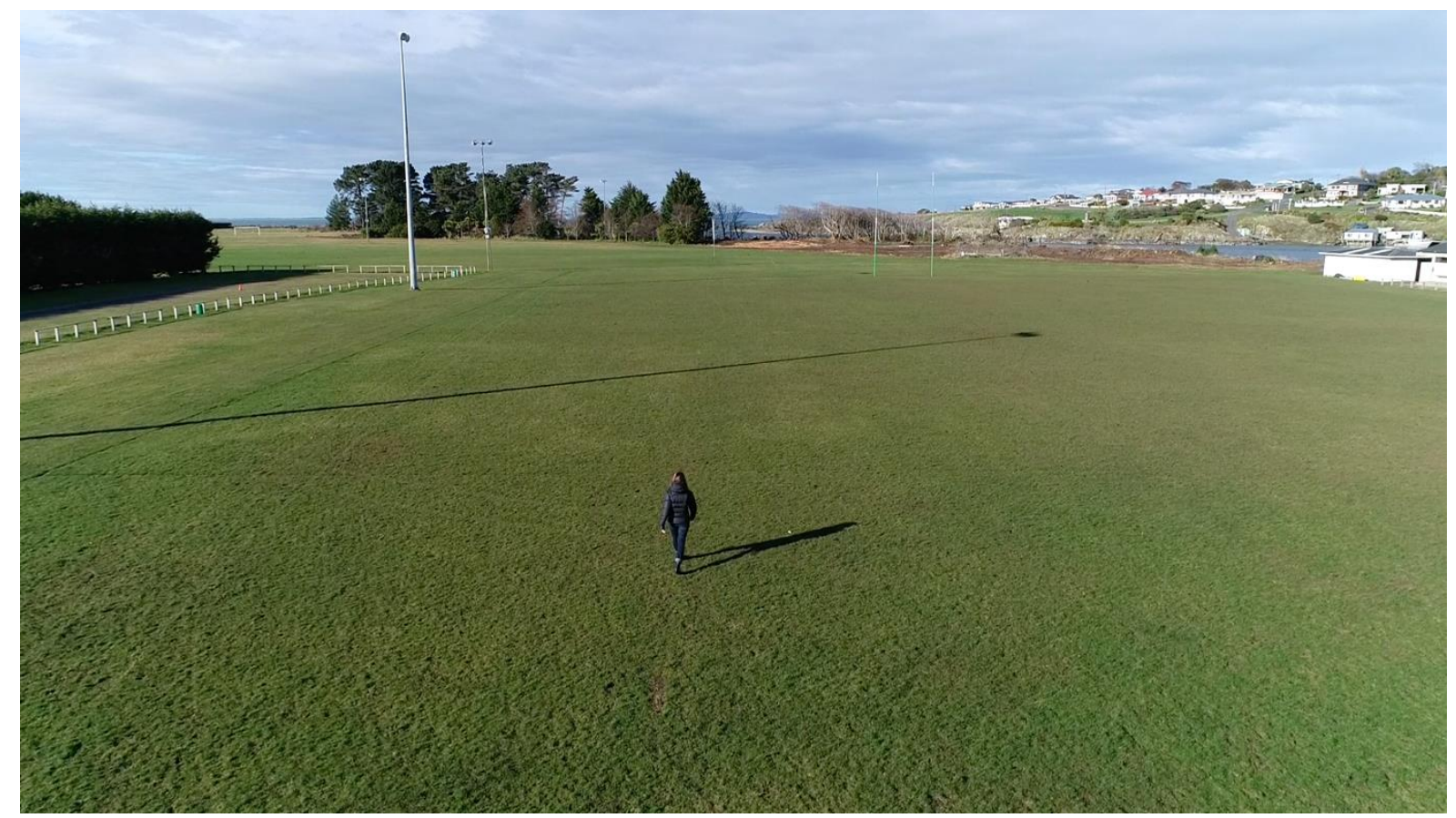

Figure 2. Frame from Looking Forward, Walking Down, drone cinematography by Arthur Steinhauser.

In early 2019 I decided to visit once again, and this time to try and travel out to the Tìtî/Muttonbird Islands, as I had been hearing so much about this ancient and precious mahinga kai (food gathering place) and the food collection that continues today. I did not go with the expectation that I could land, although I had been given the names of two islands that my ancestors had rights to, but I wanted to get close. ${ }^{87}$ To do this, I organised a passage on a boat that was dropping muttonbirders off at the start of the season.

\section{March 2019: Visit Three}

It was not long after attending the funeral for my beloved birth father that I travelled for the third time south, to the land of his whannau, taking two cameras and my husband as second camera and company, anticipating we might be navigating difficult emotional waters. Twentyone of the 39 Tīiti Islands around Rakiura are "Beneficial Islands," where Ngāi Tahu rights holders, beneficiaries, travel each year in order to harvest the young tîti ${ }^{88}$ We boarded the boat at Bluff at midnight, and set off to the west of Rakiura, along with around 15 birders, 3 crew, 3 large dogs, and a great deal of gear. The night was cold but the company warm; when it was discovered that I was distantly related to local iwi I was asked who? What names? And then, among the exhortations to meet this person or that, someone said "you're one of us." What powerful words they were! 
After a fitful sleep on a small bunk, we rose as the sky began to lighten, and an incredible view greeted us. We were still travelling south. The dark sky was touched with a rose tinge along Rakiura's hills to our left. To our right, the first of the Tìti//Muttonbird Islands appeared, dotted in the pristine sea. Behind the boat, mollymawks and a few dark adult muttonbirds wheeled over our wake. We dropped anchor, then cargo and great containers of water were plucked off the boat by a helicopter. Then we began dropping muttonbirders at their islands.

It was with mixed feelings that I watched them leave, full of excitement, calling out to each other best wishes for a good season. Janet Carsten warns that in trying to reconnect with my birth past, and make a new history for myself, I would also find what had been irreparably lost, and experience "vivid and painful reminders of the missing threads of continuity." 89 What I was witnessing was belonging in action, created through a reproduced, and shared, centuriesold tradition. ${ }^{90}$ But it was hard to be melancholy on such a beautiful day, and when I talked to someone about how the young birds were killed, I was pleased to not be going.

Home again, looking through the footage, I saw that that this time my images held more of the ineffable, that the immense mystery of the sea seemed to more closely align with the longing of adoption. In the edit I was pulled towards making a factual documentary by the unique qualities of muttonbirding itself, absenting myself and why I was on the boat. After many iterations, in the short essay film Near and Far, I found a way to tell the story of this unique practice alongside my own complex relationship to it.

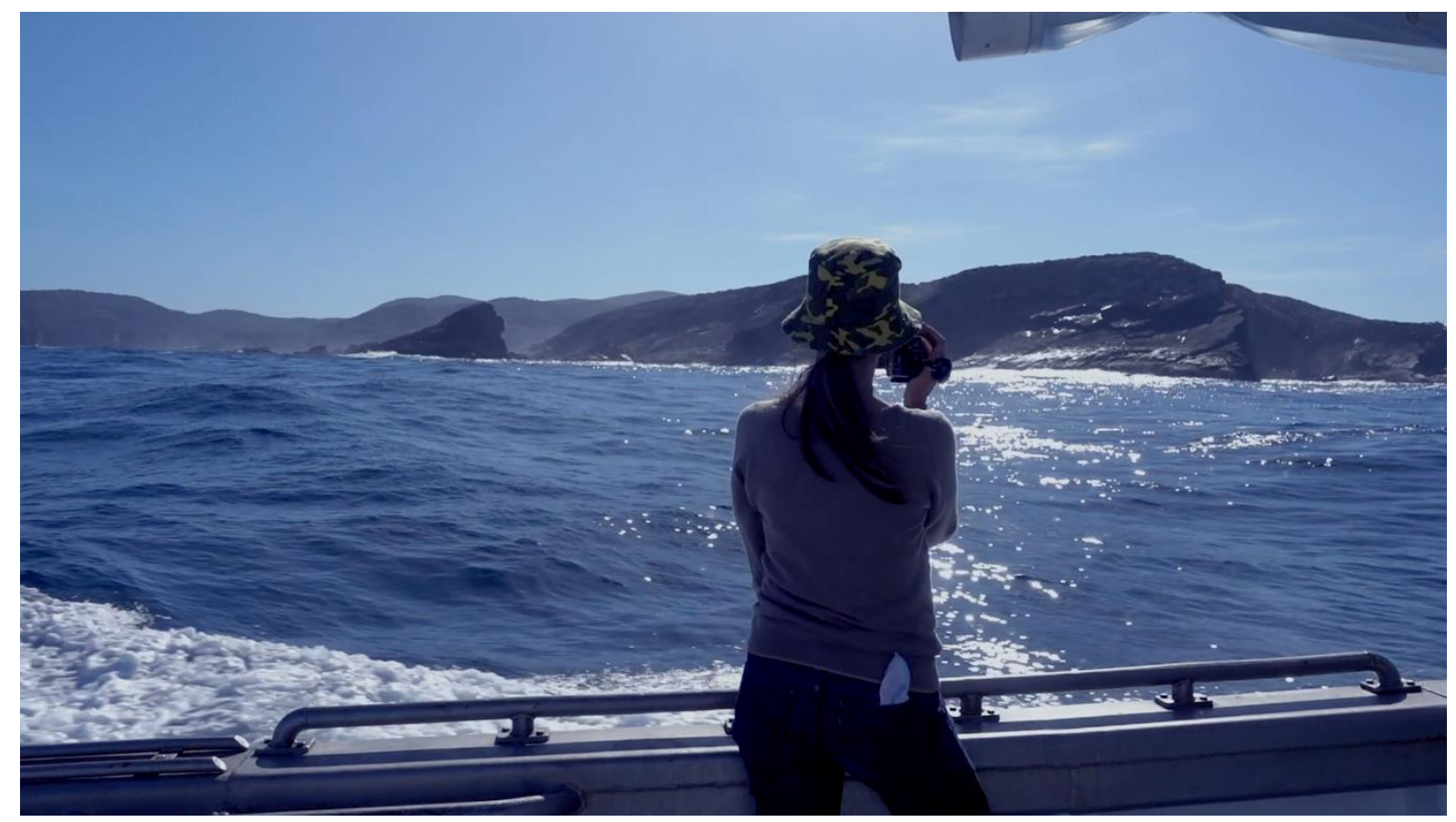

Figure 3. Frame from Near and Far, second camera by Jonathan Roper.

\section{Conclusion}

Travelling to Riverton/Aparima was part of my roots journey, but lost belongings are not just lying around to be picked up like stones on the shoreline. The actions of searching and making are what constitute belonging - it is a material practice of piecing fragments together, and of 
actively "(re)inhabiting" events. ${ }^{91}$ I saw the river that James Leader drowned in. I felt the cold wind blowing off to the sea onto the properties where John and his family farmed, and I travelled on the wide blue sea that my ancestors rowed through to muttonbird. In the macrocarpa trees and the bush, I experienced Game's "self in connection," an in-between place of being both in- and outside our selves. ${ }^{92}$ Yngvesson reminds me that roots journeys are bittersweet, and that moments of connection alleviate what is a "process of self-constitution that is ongoing, painful, and turbulent, challenging any sense of a stable ground of belonging." 93

But I argue that shooting video gave me agency, encouraging attachment; I looked in a particular, more intense way, and I captured moments of place to take home with me, and through creative practice, make mine. Filmmaker Chris Marker writes that rather than remembering the month of January when he shot Sans Soleil in Tokyo, he remembers the images; "they have substituted themselves for my memory." 94 Furthermore, in filming myself walking on the land I undertook an "embodied experience," momentarily departing from my ordinary relationship with my body. ${ }^{95}$ Although I did not experience the ghosts that I had hoped to, Holloway and Kneale remind me that going ghost hunting is fruitful, and in coming up against "hesitancy and imponderability, excess and ineffability" we are given the chance for "newly charged lines of thought and enchanted modes of apprehension." "96 "enchantment" with the place that my tūpuna called home was subtle, and only became apparent as I worked through the intricacies with my creative practice. As every powerful experience changes us, so this has changed me. I have written Riverton/Aparima on and in myself.

\footnotetext{
${ }^{1}$ Anne Else, A Question of Adoption (Wellington: Bridget William Books, 1991).

${ }^{2}$ Maria Haenga-Collins, "Closed Stranger Adoption, Māori and Race Relations in Aotearoa New Zealand, 1955-1985" (PhD thesis, Australian National University, 2017).

${ }^{3}$ Anne Else, "Adoption," Te Ara-The Encyclopedia of New Zealand, http://www.TeAra.govt.nz/en/adoption/page-4.

${ }^{4}$ Some of the writers I quote do not use macrons, others use the southern dialect, for example "Kāi Tahu" and "mahika kai" in place of "Ngāi Tahu" and "mahinga kai." I follow the spelling and use of macrons as per the Ngāi Tahu website: https://ngaitahu.iwi.nz/

${ }^{5}$ The Blue Book (Ngāi Tahu Māori Trust Board, compiled 1925) is a census of Ngāi Tahu alive in 1848. It is only necessary to have one kaumātua (elder) in the Blue Book, and no other Māori ancestors, to officially belong to the tribe. I have four.

${ }^{6}$ Betty Jean Lifton, Journey of the Adopted Self: A Quest for Wholeness (New York: Basic Books, 1994), 4.

${ }^{7}$ Pauline Kenny, Daryl Higgins, Carol Soloff, and Reem Sweid. "Past Adoption Experiences: National Research Study on the Service Response to Past Adoption Practices," Australian Institute of Family Studies, Research Report No. 21 (August 2012), https://aifs.gov.au/sites/default/files/publicationdocuments/rr21.pdf

${ }^{8}$ Meghann Ormond, "Adoption, Genealogical Bewilderment and Heritage Bricolage," in After Heritage: Critical Geographies of Heritage from Below, ed. Hamzah Muzaini and Claudio Minca (Cheltenham: Edward Elgar, 2018), 148-68.

${ }^{9}$ Anne Harris and Enza Gandolfo, "Looked at and Looked over or: I Wish I was Adopted," Gender, Place \& Culture 21, no. 5 (2014): 573.

${ }^{10}$ Helen Brookfield, Steven D Brown, and Paula Reavey, "Vicarious and Post-Memory Practices in Adopting Families: The Re-Production of the Past through Photography and Narrative," Journal of Community \& Applied Social Psychology 18, no. 5 (2008): 474-91.

${ }^{11}$ Ormond, "Genealogical Bewilderment."

${ }^{12}$ Lifton, Journey of the Adopted Self, 4.

${ }^{13}$ Peter Geschiere, The Perils of Belonging: Autochthony, Citizenship, and Exclusion in Africa and
}

Journal of New Zealand Studies NS29 (2019), 75-88 https://doi.org/10.26686/jnzs.v0iNS29.6263 
Europe (Chicago: University of Chicago Press, 2009), 2.

${ }^{14}$ Catherine Nash, "Genealogical Identities," Environment and Planning D: Society and Space 20, no. 1 (2002): 27-52, https://doi.org/10.1068/d314

${ }^{15}$ Avril Bell, “'Half-Castes' and 'White Natives': The Politics of Māori-Pākehā Hybrid Identities,” in Cultural Studies in Aotearoa New Zealand: Identity, Space and Place, ed. Claudia Bell and Steve Matthewman (Oxford: Oxford University Press 2005): 121-38. See also Avril Bell, "Bifurcation or Entanglement? Settler Identity and Biculturalism in Aotearoa New Zealand," Continuum 20, no. 2 (2006): 253-68, and Avril Bell, "Dilemmas of Settler Belonging: Roots, Routes and Redemption in New Zealand National Identity Claims "The Sociological Review 57, no. 1 (2009): 145-62.

${ }^{16}$ Josie Arnold, "Practice Led Research: Creative Activity, Academic Debate, and Intellectual

Rigour," Higher Education Studies 2, no. 2 (2012): 9-24.

${ }^{17}$ Carolyn Ellis, Tony E Adams, and Arthur P Bochner, "Autoethnography: An Overview," Historical Social Research/Historische Sozialforschung (2011): 273-90.

${ }^{18}$ Dwight Conquergood, "Rethinking Ethnography: Towards a Critical Cultural Politics,"

Communications Monographs 58, no. 2 (1991): 179-94.

${ }^{19}$ Esther Fitzpatrick, "The Art of Letting the Ghost Come Back: A Serendipitous Tale of Exploring the Complex Issue of Becoming a Pākehā Educator" (PhD thesis, University of Auckland, 2016).

${ }^{20}$ Beth Blue Swadener and Kagendo Mutua, "Decolonizing Performances: Deconstructing the Global Postcolonial," in Handbook of Critical and Indigenous Methodologies, ed. Norman K Denzin, Ynonna S Lincoln, and Linda Tuhiwai Smith (Thousand Oaks: SAGE Publications, 2014), 31-44.

${ }^{21}$ Cristina M Dominguez, "Haunting Wholeness: Inviting Ghosts on the Bridge So We Can

Transform," Qualitative Inquiry (2018): 3, https://doi.org/10.1177/1077800418809122

${ }^{22}$ Arthur P Bochner, Carolyn Ellis, and Lisa M Tillmann-Healy, "Relationships as Stories; Accounts, Storied Lives, Evocative Narratives," in Communication and Personal Relationships ed. Kathryn Dinda and Steve Duck (New York: John Wiley 2000): 13-30.

${ }^{23}$ Stacey Holman Jones, "Autoethnography: Making the Personal Political," in Collecting and Interpreting Qualitative Materials, ed. Norman K Denzin and Yvonna S Lincoln (Thousand Oaks: Sage Publications, 2008), 235.

${ }^{24}$ Reena Veralynne Kainamu, "Say Our Beautiful Names: A Māori Indigene's Autoethnography of Women-Self-Mother" (University of Auckland, 2013), 11.

${ }^{25}$ Hana O'Regan, Ko Tahu, Ko Au-Käi Tahu Tribal Identity (Christchurch, New Zealand: Horomaka Publishing, 2001), 54-55.

${ }^{26}$ Angela Wanhalla, "Ngāi Tahu Historiography," History Compass 5, no. 3 (2007): 802-17, https://doi.org/10.1111/j.1478-0542.2007.00427.x

${ }^{27}$ Linda Tuhiwai Smith, Decolonizing Methodologies: Research and Indigenous Peoples, 2 nd ed. (London: Zed Books Ltd, 2013), 72.

${ }^{28}$ Bochner et al., "Relationships as Stories."

${ }^{29}$ Paul Whitinui, "Indigenous Autoethnography: Exploring, Engaging and Experiencing "Self" as a Native Method of Inquiry," Journal of Contemporary Ethnography 43, no. 4 (2013): 461, https://doi.org/10.1177/0891241613508148

${ }^{30}$ Keyan G Tomaselli, Lauren Dyll, and Michael Francis, “'Self' and 'Other': Auto-Reflexive and Indigenous Methodologies," in Handbook of Critical and Indigenous Methodologies, ed. Norman K Denzin, Ynonna S Lincoln, and Linda Tuhiwai Smith (Thousand Oaks: Sage Publications, 2014): $347-72$.

${ }^{31}$ Barbara Yngvesson and Maureen A Mahoney, “"As One Should, Ought and Wants to Be' Belonging and Authenticity in Identity Narratives," Theory, Culture \& Society 17, no. 6 (2000): 83. ${ }^{32}$ Mieke Bal and Sherry Marx-MacDonald, Travelling Concepts in the Humanities: A Rough Guide (Toronto: University of Toronto Press, 2002), 23.

${ }^{33}$ Jacques Derrida, Spectres De Marx: L'état De La Dette, Le Travail Du Deuil Et La Nouvelle Internationale (Specters of Marx: The State of the Debt, the Work of Mourning and the New International) (London: Routledge, [1993] 2012).

${ }^{34}$ Kate Shipley Coddington, "Spectral Geographies: Haunting and Everyday State Practices in Colonial and Present-Day Alaska," Social \& Cultural Geography 12, no. 7 (2011): 748, https://doi.org/10.1080/14649365.2011.609411

Journal of New Zealand Studies NS29 (2019), 75-88 https://doi.org/10.26686/jnzs.v0iNS29.6263 
${ }^{35}$ Eve Tuck and C Ree, "A Glossary of Haunting," in Handbook of Autoethnography, ed. Stacy Holman Jones, Tony Adams, and Carolyn Ellis (California: Left Coast Press Inc, 2013), 642.

${ }^{36}$ Avery Gordon, Ghostly Matters: Haunting and the Sociological Imagination (Minnesota:

University of Minnesota Press [1997] 2008), xix, 22.

${ }^{37}$ Fitzpatrick, "Letting the Ghost Come Back."

${ }^{38}$ Derrida, Spectres de Marx, 11.

39 "Local and General," Otago Witness, issue 1975 (31 December 1891), 17, https://paperspast.natlib.govt.nz/newspapers/OW18911231.2.52

${ }^{40}$ Rhys Richards, "Murihiku" Re-Viewed; a Revised History of Southern New Zealand from 1804 to 1844 (Wellington: Lithographic Services 1995), 11.

${ }^{41}$ Eva Wilson, Hakoro Ki Te Iwi: The Story of Captain Howell and His Family (Invercargill: Invercargill Times Printing, 1976).

${ }^{42}$ Kate Stevens, "'Gathering Places': The Mixed Descent Families of Foveaux Strait and Rakiura/Stewart Island, 1824-1864” (Honours thesis, University of Otago, 2008), 45.

${ }^{43}$ Richards, Murihiku, 28.

${ }^{44}$ Angela Wanhalla, Matters of the Heart: A History of Interracial Marriage in New Zealand (Auckland: Auckland University Press, 2013), 8.

${ }^{45}$ Vincent O'Malley, Beyond the Imperial Frontier: The Contest for Colonial New Zealand (Wellington: Bridget Williams Books Ltd, 2014), 21.

${ }^{46}$ Atholl Anderson and Brian Niven, Race against Time: The Early Maori-Pakeha Families and the Development of the Mixed-Race Population in Southern New Zealand (Otago Hocken Library, University of Otago, 1991), 6.

${ }^{47}$ Atholl Anderson, The Welcome of Strangers: An Ethnohistory of Southern Maori AD 1650-1850 (Dunedin: University of Otago Press, 1998), 195.

${ }^{48}$ Stevens, "Gathering Places," 3.

${ }^{49}$ June Stark, Journal of a Rambler: The Journal of John Boultbee (Auckland: Oxford University Press, 1986), 102.

${ }^{50}$ Wanhalla, Matters of the Heart, 5.

${ }^{51}$ Wanhalla, Matters of the Heart, 5.

${ }^{52}$ David Haines, "In Search of the 'Whaheen': Ngai Tahu Women, Shore Whalers, and the Meaning of Sex in Early New Zealand," in Moving Subjects: Gender, Mobility, and Intimacy in an Age of Global Empire, ed. Tony Ballantyne and Antoinette M Burton (Illinois: University of Illinois Press, 2009), 54.

${ }^{53}$ Wanhalla, Matters of the Heart, 2.

${ }^{54}$ Bill Dacker, Te Mamae Me Te Aroha: The Pain and the Love-A History of Kai Tahu Whānui in Otago, 1844-1994 (Dunedin: University of Otago Press, 1994), 1.

${ }^{55}$ O'Regan, Ko Tahu, 137.

${ }^{56}$ The term half-caste and three-quarter caste were extensively used in official documents of the time; however, I use the term mixed-race as this has less negative "blood-rule" connotations.

${ }^{57}$ Paul Meredith, "A Half-Caste on the Half-Caste in the Cultural Politics of New Zealand," in Maori Und Gesellschaft: Scientific and Literary Essays, ed. Hartmut Jäcksch (Berlin: Mana-Verlag, 2000), 2 .

${ }^{58}$ Stan Grant, On Identity (Melbourne: Melbourne University Press, 2019).

59 "Riverton Native School," Western Star 1077, 30 October 1886, 2, https://paperspast.natlib.govt.nz/newspapers/WSTAR18861030.2.9.1

${ }^{60}$ Stuart Hall, "Constituting an Archive," Third Text 15, no. 54 (Spring 2001): 91, https://doi.org/10.1080/09528820108576903

${ }^{61}$ Tim Cresswell, "Value, Gleaning and the Archive at Maxwell Street, Chicago," Transactions of the Institute of British Geographers 37, no. 1 (2012): 164, https://doi.org/10.1111/j.14755661.2011.00453.x

${ }^{62}$ Tim Cresswell, Place: An Introduction (United Kingdom: Wiley Blackwell, [2004] 2015), 17.

${ }^{63}$ Conquergood, "Rethinking Ethnography," 180.

${ }^{64}$ Tim Ingold, Making: Anthropology, Archaeology, Art and Architecture (New York: Routledge, 2010), 1 .

Journal of New Zealand Studies NS29 (2019), 75-88 https://doi.org/10.26686/jnzs.v0iNS29.6263 
${ }^{65}$ Ann Nation, "Betwixt and Between: An Exploration of Adoption Reunion Realities Following New Zealand Non-Maori Adoptions, from a Psychodynamic Perspective," NZAP Forum: The Journal of The New Zealand Association of Psychotherapists 7 (2001): 102.

${ }^{66} \mathrm{He}$ gave me Jane Arnett's pepeha. Jane was an ancestor of mine, so I was bold enough to borrow it for myself, and record a hesitant version of it on video for my research practice:

Ko Aoraki te Mauka

Ko Te Ara a Kewa te Wai

Ko Rakaihautu, ko Paikea ngā Tangata

Ko Uruao, ko Takitimu ngā waka

Ko Waitaha, ko Ngāti Mamoe, ko Ngāi Tahu, ko Pākehā ngā Iwi

Ko Christine Rogers taku ingoa

Tēna koutou, Tēna koutou, Tēna koutou, katoa.

${ }^{67}$ Khyla Russell, "Landscape: Perceptions of Kāi Tahu i Mua, Āianei, ā Muri Ake," in Proceedings of the Indigenous Knowledges Conference, University of Auckland, 2005 (Auckland: University of Auckland, 2007), 161.

${ }^{68}$ George Asher and David Naulls, "Māori Land, Planning Paper no. 2" (Wellington: NZ Planning Council, 1987), in Stephanie Wyse, "Colonising Her Cultural Identity: Geographies of a Hybrid Identity in Colonial Turanga" (Massey University, 2002), 19.

${ }^{69}$ O’Regan, Ko Tahu, 52.

${ }^{70}$ Jeff Malpas, Place and Experience: A Philosophical Topography, second edition (New York: Routledge, 2018), 4.

${ }^{71}$ Tomaselli, Dyll, and Francis "'Self' and 'Other," 349.

${ }^{72}$ Christine Rogers "Putting the Ghost Back In: Making Rich Meaning In Video Work" in Refractory: A Journal of Media Entertainment 33 (16 October 2019), https://refractory-journal.com/putting-theghost-back-in-making-rich-meaning-in-video-work/

${ }^{73}$ Barbara Yngvesson, "Going "Home": Adoption, Loss of Bearings, and the Mythology of Roots," Social Text 21, no. 1 (2003): 17, DOI: 10.1215/01642472-21-1_74-7

${ }^{74}$ Emilie Cameron, "Indigenous Spectrality and the Politics of Postcolonial Ghost Stories," cultural geographies 15, no. 3 (2008): 384, https://doi.org/10.1177/14744474008091334

${ }^{75}$ Arthur P Bochner and Carolyn Ellis, "An Introduction to the Arts and Narrative Research: Art as Inquiry," Qualitative Inquiry 9, no. 4 (2003): 507.

${ }^{76}$ Kate Stevens, "'Every Comfort of a Civilized Life': Interracial Marriage and Mixed Race Respectability in Southern New Zealand," Journal of New Zealand Studies, no. 14 (2013): 87.

${ }^{77}$ Damien Chaney and Christina Goulding, "Dress, Transformation, and Conformity in the Heavy

Rock Subculture," Journal of Business Research 69, no. 1 (2016), 155-65, https://doi.org/10.1016/j.jbusres.2015.07.029

${ }^{78}$ Vanessa Agnew, "Epilogue: Genealogies of Space in Colonial and Postcolonial Reenactment," in Settler and Creole Reenactment, ed. Vanessa Agnew, Jonathan Lamb, and Daniel Spoth (London: Palgrave Macmillan, 2009), 300.

${ }^{79}$ Marsha Berry, "Being There: Poetic Landscape," Coolabah 11 (2013): 94.

${ }^{80}$ Sarah Pink, "Walking with Video," Visual Studies 22, no. 3 (2007): 80, https://doi.org/10.1080/14725860701657142

${ }^{81}$ Elspeth Probyn, Outside Belongings (New York: Routledge, 1996), 12.

${ }^{82}$ Marita Sturken, "The Politics of Video Memory: Electronic Erasures and Inscriptions," in

Resolutions: Contemporary Video Practices, ed. Michael Renov and Erika Suderburg (Minneapolis: University of Minnesota, 1996), 1.

${ }^{83}$ Ann Game, "Belonging: Experience in Sacred Time and Space," in Timespace: Geographies of Temporality, ed. Jon May and Nigel Thrift (London: Routledge, 2001), 238.

${ }^{84}$ Laura Rascaroli, "The Essay Film: Problems, Definitions, Textual Commitments," Framework: The Journal of Cinema and Media 49, no. 2 (2008): 39, http://www.jstor.org/stable/41552525

${ }^{85}$ Dean Keep, "Smartphones and Evocative Documentary Practices," in Mobile Story Making in an Age of Smartphones, ed. Max Schleser and Marsha Berry (Switzerland: Springer, 2018): 47, https://doi.org/10.1007/978-3-319-76795-6_5

${ }^{86}$ The film was selected to screen at the Ethnografilm Festival, Paris, 2019.

Journal of New Zealand Studies NS29 (2019), 75-88 https://doi.org/10.26686/jnzs.v0iNS29.6263 
${ }^{87}$ Neville Wilson, son of historian Eva Wilson, gave me the names: William Leader had rights to Puketakohe; and Georgina Green, Victoria Arnett and Rua Arnett had rights to Poutama Island.

${ }^{88}$ Harry Charles Evison, The Ngai Tahu Deeds: A Window on New Zealand History (Christchurch, Canterbury University Press, 2006), 260.

${ }^{89}$ Janet Carsten, “'Knowing Where You've Come From': Ruptures and Continuities of Time and Kinship in Narratives of Adoption Reunions," Journal of the Royal Anthropological Institute 6, no. 4 (2000): 696.

${ }^{90}$ Anne-Marie Fortier, Migrant Belongings: Memory, Space, Identity (Oxford: Berg, 2000), 1.

${ }^{91}$ Yngvesson, "Going 'Home,"” 13.

${ }^{92}$ Game, "Belonging," 228.

${ }^{93}$ Yngvesson, "Going 'Home,"” 21.

${ }^{94}$ Sturken, "Video Memory," 1.

${ }^{95}$ Stefan Schutt and Marsha Berry, "How the 'I' Sees it: The Maker, the Researcher and the Subject at the Juncture of Memory and History," in Discourse, Power, and Resistance Down Under, ed. Mark Vicars, Tarquam McKenna, and Julie White (The Netherlands: Sense Publishers, 2012), 117, https://doi.org/10.1007/9789462090378 010

${ }^{96}$ Julian Holloway and James Kneale, "Locating Haunting: A Ghost-Hunter's Guide," cultural geographies 15, no. 3 (2008): 309, https://doi.org/10.1177/14744744008091329 